economic activity in Britain. (Two centuries ago, James Watt and Matthew Boulton would not have been able to build a business selling new-fangled steam engines had it not been for the existence of joint-stock companies to moderate financial risk and commercial banks to lend them money.) On the face of things, this common theme implies a bigger budget for the smallest of the research councils. Whether the Office of Science and Technology will succeed in persuading other government departments of the need for legislative and regulatory change is another matter.

The panels representing the harder sciences naturally have more specific recommendations to make. Thus the health and life sciences panel urges greater investment (by industry as well as government) in the applications of molecular biology in fields as different as the design of new drugs, the development of diagnostic techniques and gene therapy. But the panel says the time has come to carry the search for human genes into an understanding of the working of the cell and of whole organisms, it has interesting things to say about the importance of understanding the mechanism of human ageing in the delivery of health care and it asks for a better understanding of cognition not simply so as to be able to deal with psychiatric illnesses, but also for the everyday improvement of personal efficiency. The panel backs no winners and need not constrain the decisions of the research councils in the months ahead.

So has the exercise been worthwhile? Certainly, it can have done no harm. It should also be instructive for the British government that many of the foresight panels have found themselves suggesting what the government rather than the research community should do next. Let us hope that those in government pay heed. It is also something to be grateful for that none of the panel reports will necessarily constrain the way in which the research councils do business. To be sure, on matters such as the future of thermonuclear fusion research (on which the energy panel is lukewarm, as it is on windmills), the government may decide it had better listen, but will find itself carried along by the European programme in this field. And while the panel on communications applauds British competence in the field of optoelectronics, nobody seems to have spotted that Britain lags behind the United States, Japan and France in potentially important fields such as high-precision laser spectroscopy and the design of solid-state lasers.

What happens next? In principle, British research councils are now expected to take account of the foresight documents when making new awards. But the constraint will not be as drastic as many have feared. Indeed, the most likely development is that those seeking to make their projects fundable will read the reports that concern them (uniformly priced at $£ 15.00$ at HMSO) and adjust their applications accordingly. That in itself could be valuable. Foresight, as the panels have practised it, includes much interesting hindsight about the real reasons why British industry has fallen into uncompetitive ways. The panel on the construction industry, with its lament over falling research spending and productivity, could have been written in the 1950 s, and probably was.

\section{Good manners win out}

\section{Disputes about priority have no place in the seemly publication of research data.}

Almost the only public recognition of research well done is the recognition that comes from published research articles in respectable journals. That is why researchers hang so eagerly on the communications they receive from editors and why they occasionally react with a blend of anger, depression and scorn to the news that what they wish to say cannot be published in the journal of their choice. But the authorship of scientific articles is now more than a matter of pride; so long as grant-making agencies and appointments committees rely, as they do and should not, on bibliometric indices, reference to a person in the 'acknowledgements' section of a paper rather than as an author may damage his career.

An important article in this month's Nature Genetics describing the possible localization on chromosome 6 of a locus of inherited susceptibility to schizophrenia (S. Wang et al. Nature. Genet. 10, 41-46; 1995) appears to have offended at least two groups of collaborators.

First, the principal author of the article, Dr Scott R. Diehl of the National Institute of Dental Research (NIDR) at the National Institutes of Health (NIH), began on his study at the Virginia Commonwealth University, to which he was recruited in 1988 by Professor Kenneth S. Kendler. Diehl, with the status of principal investigator, was then awarded a research grant to look for evidence of genetic predisposition to schizophrenia in an extensive set of data collected in Ireland by Kendler, working in collaboration with Irish psychiatrists (on both sides of the Irish border). Then, it appears, Diehl and Kendler fell out over ownership of the interpretation of the data, Diehl moved to NIDR and NIH (asked to adjudicate) said that the two should seek an accommodation but that, otherwise, each should be free to publish separately.

Second, Kendler, in collaboration with a new collaborator, Dr Richard E. Straub, had analysed the original and supplementary data and had also prepared a manuscript for publication; a version of this was sent to Diehl on 15 March, among other things for his approval of the inclusion of his name (third in a list of eleven), which offer was declined. Diehl could hardly have accepted, knowing that his own article was being reviewed by Nature Genetics. That article acknowledges that the data had been "collected in Ireland", includes Kendler and a number of Irish names among its acknowledgements but does not mention the Virginia Commonwealth University, the Health Research Board in Dublin or the Queen's University, Belfast.

Technically, nobody has behaved wrongly. Diehl has NIH approval for separate publication. So has Kendler. If NIH had followed Solomon, it would have recommended that the article and the authors' list should be chopped in half, to see how the participants reacted. But what about the proper Irish interests, where NIH's writ does not run? Personal disputes about priority should be buried in the interests of seemly publications, especially when third parties are concerned. 